\title{
Multitude in Cultural Complexities in Asia
}

\author{
Johannes Widodo ${ }^{1, *}$ \\ ${ }^{1}$ National University of Singapore, Singapore
}

\begin{abstract}
The genesis of human settlements is a continuous process of production and layering of patterns, forms and spaces in different scale levels across historical periods. Our urban morphology is the product of the cosmopolitan communities, the articulation of the multi layered tangible and intangible urban traditions and modernization processes. Diversity, eclecticism, fusion, acculturation, adaptation, are the nature of our architecture and urbanism.

However, at present, we are in an urgent need to find resolutions to address serious problems posed by the climate change, ideological conflicts, economic greediness, depletion of resources, and social justice. One of an essential elements in humanity is empathy, and this empathy has been anesthetized or lost due to ignorance and greed in almost all aspects of our relationships with others and nature. The design and planning profession and education should reflect on the mistakes that have been created which have caused cultural, social, and environmental issues. We need to reconsider our present practices, i.e., to reflect on, to interrogate and perhaps to present alternatives to our existing pedagogical paradigm.
\end{abstract}

Keywords: cosmopolitan identity, contemporary crisis, ethics, architectural education

\section{Contemporary Crisis in Cosmopolitan Identities}

For centuries sustainable cosmopolitan settlements have been developing around the "Mediterranean Sea of Asia", (referring to the coastal regions around the South China Sea, Java Sea, and Malacca Strait) since the establishment of the inter-insular and inter-continental maritime trading, called "Bumantara" and "Nusantara", located at the center of international economic networks, and in-between maritime corridors for human migration and cultural exchanges. Here the cosmopolitan culture has been developing through complex layering processes of various cultures, ideologies, economies, and ecosystems sustained over a long historical period from the past to the present and will continue.

At present we are in an urgent need to find resolutions to address serious problems posed by the climate change, ideological conflicts, economic greed, depletion of resources, and the threat to social justice.

Southeast Asia has been disturbed by Rohingya refugee crisis, violent separatist threat in Marawi, the rise of religious and racial intolerance in Indonesia and Malaysia, continuous conflicts in Southern Thailand and Myanmar, conflicting territorial claims in South China Sea, environmental damage due to excessive reclamations in Melaka, Johor, and the Jakarta, persistent flooding in various cities and places, gaps between the rich and the poor, etc.

These challenges are not only becoming the concern of our generation, but seriously affecting our future generations as well. Without radical change in our attitude towards other human being, built environment, and natural environment, the future of human civilization and the survival of the planet earth are very discouraging. Therefore, Ethics becomes fundamentally important as the focus in education of the next generation, to change our behavior and perspective in saving and caring of our common planet and living habitat.

Until today the pedagogy of many Architectural education in different countries in Asia have not change much and still continuing the colonial legacies or the old school of thought, based on "teaching" paradigm and "project based" study.

There are widening gaps between academic learning and the reality outside campus, between theory and practice, between global and local, between specialization and broad-based education, between the old and the young. Our architectural education needs to develop a design-research culture to deal with social and environmental changes. Pedagogical reform is desperately needed at this moment of crisis.

Old ways of teaching Architecture is not effective anymore to deal with the multitude and the scale of the contemporary crisis. The challenge today is how to enable our students to be more resilient, critical, creative, innovative, and pro-active. Also on how to develop both research- and design capacity through research by design and design by research.

Another challenge is to re-connect the education with the profession, the academia with the common people, theory with practice, and behavior with ethics. In short, the biggest need today is to restore the original ideals of

Corresponding author: jwidodo@nus.edu.sg 
holistic Architectural education, so the new generation of Architects will be able to become a problem-solver and "vanguard" of our civilization and common planet.

\section{Return to the Fundamentals of Architectural Education}

The fundamental principles of Architectural education was clearly stated by Marcus Vitruvius Pollio who lived in the $1^{\text {st }}$ century BCE in his "Ten Books of Architecture", Chapter I, "The Education of the Architect".

According to Vitruvius, the architect should be equipped with multi-disciplinary knowledge, as the ground for practice and theory. Practice is learned through continuous exercise of manual work based on the design drawings. Theory is the ability to demonstrate and explain the design productions. He stressed the complementarity of theory and practice to gain credibility as an architect.

"It follows, therefore, that architects who have aimed at acquiring manual skill without scholarship have never been able to reach a position of authority to correspond to their pains, while those who relied only upon theories and scholarship were obviously hunting the shadow, not the substance. But those who have a thorough knowledge of both, like men armed at all points, have the sooner attained their object and carried authority with them."

Vitruvius further explained that a good architect is made of two inseparable factors: natural ability or talent plus training.

"Let him be educated, skilful with the pencil, instructed in geometry, know much history, have followed the philosophers with attention, understand music, have some knowledge of medicine, know the opinions of the jurists, and be acquainted with astronomy and the theory of the heavens."

An architect shall be educated and knowledgeable in drawing and sketches to show the appearance of the work that he proposes. For this, he must master geometry, optics, shadow, perspective, and building costing. He must learn history to understand the ideas and concepts behind forms and decorations.

Philosophy is needed to make an architect "highminded and not self-assuming, but rather renders him courteous, just, and honest without avariciousness.". Vitruvius further stressed:

"This is very important, for no work can be rightly done without honesty and incorruptibility. Let him not be grasping nor have his mind preoccupied with the idea of receiving perquisites, but let him with dignity keep up his position by cherishing a good reputation. "

He must also understand the principles of law, so that, before he begins to build, he may be careful not to leave any possible dispute with the client after the works are finished, and so that in drawing up contracts the interests of both employer and contractor may be wisely safe-guarded.

Another basic knowledge of physics to deal with natural and environmental elements like water and wind.
The fundamental principles of physics shall be learned from philosophy to prevent damages to the building. Architect must also understand music, so that he may have knowledge of the canonical and mathematical theory to deal with acoustical issues and properties.

"From astronomy we find the east, west, south, and north, as well as the theory of the heavens, the equinox, solstice, and courses of the stars. If one has no knowledge of these matters, he will not be able to have any comprehension of the theory of sundials."

An architect shall also have a knowledge medicine, so he can account on the questions of climates, air and water quality, and the healthiness or unhealthiness of sites. Without these considerations the healthiness of a dwelling cannot be assured.

Mastering Architecture takes time and cannot be rushed, because the learning is very vast in extend. Although it seemingly impossible for a human to comprehend and to memorize such a considerable number of studies, but because of many commonality and overlapping of one and another knowledge, it can be achieved easily. Nevertheless, as a human architect, he will not be able to achieve perfection. Therefore, make a good architect, even if someone has a great talent, training and capacity building in all subjects are undeniably needed.

"I think that men have no right to profess themselves architects hastily, without having climbed from boyhood the steps of these studies and thus, nursed by the knowledge of many arts and sciences, having reached the heights of the holy ground of architecture."

\section{Restoring Architectural Pedagogy: from Teaching to Learning}

At present, Architectural education has been strayed too far from the ideals as stated by Vitruvius. Reformation of the pedagogy in Architectural education from teaching to learning in developing the students' affective, cognitive, and psychomotor holistically is not optional anymore, but has become imperative.

Research, education, and practice in architecture should be based on the reality on the ground and not just based on alien theories. Design should be based on the understanding of the real contextual problems, to formulate sensible, sensitive, and holistic solutions.

Ethics and empathy must be reinstated in our students' heart and mind to lead them in the problem solving and designing for the future by reiterating the inherent relationships of ethics, art, science, and technology in Architecture.

Learning shall be aimed to the understanding of self by knowing the local history, paradigms, and practices in relation to the general history of humanity, to replace the narrow-exclusive-chauvinistic paradigms with a more open-inclusive-reflective paradigm.

Discourses and debates on the local identity in relation to the universal aesthetical and ethical values need to be revived through the rediscovering process of links, layers, and continuity of nature, culture, and architecture across national boundaries. This can be 
achieved by building a comprehensive database and critical assessments of global and Asian architectural legacies and heritages.

The design studio problem-based learning and training shall be directed to the production of culturally sensitive, socially responsible, environmentally sustainable design solutions. Design shall be restored as the core of Architectural education, and our research especially in Asia - shall be aimed to the production of new knowledge and not just recycling old knowledge as consumer, in the spirit of openness and sharing.

By these efforts, the multitude of cultural complexities in Asia will not be seen as liability or threat, but as the strength of Asian identity. Unity in Diversity is the key to harmonious relationship between different ideological, cultural, and social differences based on respect and camaraderie.

Architect, guided by his restored ethic and sense of responsibility, will be able to take a better care of our common home and environment.

Considering the urgency of the multitude and seriousness of the current crisis, the pedagogical reform in the Architectural education cannot be delayed anymore.

\section{References}

Ismail, R., Shaw, B.J., Ooi, G.L. (editors). (2009). Southeast Asian Culture and Heritage in Globalising World - Diverging Identities in a Dynamic Region. Surrey: Ashgate.

Widodo, J. (2002). Restoring Studio Culture and Architecture Professional Education. In Laurens, J.M. The Design Studio. Surabaya: Petra Christian University. 85-94.

Widodo, J. (2007), Towards the Renaissance of Architectural Education in Asia. Keynote paper presented in the International Conference "Challenges and Experiences in Developing Architectural Education in Asia”. Yogyakarta: UII.

Widodo, J. (2010). Current State of Modern Asian Architecture Discourse and Networking. Journal of Architectural Education, 63(2), 79-81. 